\title{
When Local Class Unionism Meets International Solidarity: A Case of Union Revitalisation in Turkey ${ }^{1}$
}

\author{
Alpkan Birelma , Özyeğin University, Turkey
}

\begin{abstract}
The article concerns the recent transformation and ensuing successes of a Turkish trade union of road transport workers called Tüm Taşıma İşçileri Sendikası (TÜMTİS). In the mid-2000s, TÜMTİS was mainly organised in small-sized freight companies having around 1500 members with collective contracts. The strategic choice of a new leadership to concentrate on a large-scale, international firm with the support of Global Unions was the turning point. The ensuing United Parcel Service campaign ended with a collective agreement for nearly 2700 new members in 2011. The union won its second large-scale organising victory at DHL in 2014. At the time of writing, a third large-scale firm is on the verge of recognition. To scrutinise this case, I use the power resources approach in a critical way. To the approach, I add an examination of the subjectivities of union leaders by drawing on the debates about different types of unionisms, importance of the ideology and motivations. I argue that the agency behind this revitalisation can be only explained by taking both its objectivities and subjectivities into account. While the class unionism embraced by TÜMTIS leaders explains the subjective side of the story, associational power from below and its meeting with international solidarity play the key role on the objective side.
\end{abstract}

\section{KEYWORDS}

Labour; trade union revitalisation; power resources; union ideology; Turkey

This article concerns the recent transformation and ensuing successes of a Turkish trade union of road transport workers called Tüm Taşıma İşçileri Sendikası (TÜMTİS). In the mid-2000s, TÜMTİS was mainly organised in traditional, small-sized delivery companies which were under the pressure of the structural shift in the freight transportation industry towards large-sized corporations. At that time, the union had around 1500 members with collective contracts. The revitalisation began after a change in leadership in 2007. The strategic choice to concentrate on a large-scale, international firm

${ }^{1}$ I would like to express my gratitude to TÜMTIS officers and leaders Göknur Marş (ex-officer), Kenan Öztürk (president), Muharrem Yıldırım (secretary of organising), Gürel Yllmaz (general secretary), Murat Küçükşahin (organiser), Demet Dinler (ex-officer), and to Terasa Conrow (Teamster's organiser) for their help and openness. I am also grateful to Michael Fichter, Jörg Bergstermann, Kenan Öztürk, Muharrem Yıldırım, Demet Dinler, Carmen Ludwig, Stefan Schmalz, Edward Webster, Ayşe Alnıaçı and anonymous reviewers of Global Labour Journal for their comments on the previous versions of this paper. This research was funded by the Friedrich Ebert Stiftung's Trade Unions in Transformation Project. I am thankful to Cihan Hüroğlu for the invitation to the project.

Global Labour Journal, 2018, 9(2), Page 215 
with the support of International Transportation Workers' Federation (ITF) and UNI Global Union was the turning point. The ensuing United Parcel Service (UPS) campaign ended with a collective agreement for nearly 2700 new members in 2011. TÜMTİS won its second large-scale organising victory at DHL, ending with an agreement for 2260 new members in 2014. At the time of writing, a third large-scale firm is on the verge of recognising the union. How could such a small union win such consistent victories against global corporations and turn into a respected and inspirational member of the international labour movement? How can this success be explained and what are the lessons to be learned from this quite astonishing revitalisation?

To scrutinise this case, I use the power resources approach in a critical way. The approach elaborately investigates the objectivities of union agency; however, it assumes a particular subjectivity, while union subjectivities are varied and complicated. I argue that TÜMTİS's revitalisation can be only explained by taking both its objectivities and subjectivities into consideration. The socialist orientation and class unionism of the TÜMTISS leaders explain the subjective side of the revitalisation, while associational power from below on the workplace level plays the key role in the objective side. The new leadership refreshed the class unionism of TÜMTIS and mobilised associational power on the workplace level. To overcome the formidable local obstacles to organising, they took the strategic choice to cooperate with the global union federations (GUFs), which soon recognised the potential of TÜMTIS and offered further support. Thereby the union increased its associational power with additional resources from the international level, and this enabled its leaders to take another strategic decision to dare to organise a big player of the sector. Local union leaders adhering to class unionism managed to connect the associational power at the workplace with the associational power on the international level. This rare conjunction has brought about the astonishing organising victories.

The article is based on field research conducted in the spring and summer of 2016. I interviewed seven of the union's elected leaders and officers individually and in groups. With most of them I met more than once. I also interviewed two United States (US) unionists, one of whom interacted with TÜMTIS as an ITF officer at the time. I spent four days with an organising officer of the union visiting already organised workplaces, meeting with workers who are part of an ongoing organising campaign, and with potential members. I also participated in two crowded meetings where the union leaders and UPS workers discussed what to demand and how to prepare for the upcoming collective bargaining. I had the chance to engage in short conversations with members and potential members during these visits and meetings.

In what follows, I first review the power resources approach, and explain how and why I reinforce it with an examination of the subjectivities of the union leaders. The second section provides a short history of TÜMTIS's remarkable revitalisation. In the last section, I analyse the process by tapping into the power resources approach reinforced with a discussion on subjectivity.

\section{The Power Resources Approach and the Issue of Subjectivity}

In the expanding literature on trade union revitalisation, the power resources approach is a prominent one, especially among European scholars. Although it might have several weaknesses in its attempt to comprehend the total complexity of social reality, just like all other models (Tilly, 1995: 1596), it is an effective way to scrutinise unions' revitalisation practices comparatively and analytically

Global Labour Journal, 2018, 9(2), Page 216 
(Frege and Kelly, 2004: 33-5; Hyman and Gumbrell-McCormick, 2013: 30-1; Schmalz and Dörre, 2016; Schmalz and Thiel, 2017; see also Schmalz, Ludwig and Webster in this issue).

The power resources model assumes that the working class in general and trade unions in particular have certain power resources from which they derive their social and political power. How to discover and access these resources, and how far and how effectively they are being used, depends on the will and capabilities of the workers and their unions. The model rests on the conceptualisation made by Wright (2000: 962) and further developed by Silver (2003: 13). Accordingly, the working class has two primary power resources, one of which, namely structural power, derives from the location of the workers within the economic structure, while the other, namely associational power, derives from workers' collective organisation.

Scholars who applied this conceptualisation in their research defined other power resources, which has opened an ongoing debate about what these resources are and how to classify them. I will use a quadruple model, which includes structural, associational, institutional and societal power resources. Institutional power marks several support mechanisms unions may tap into, such as legislative supports, mechanisms of extension of collective bargaining agreements, and participation in tripartite consultation processes (Hyman and Gumbrell-McCormick, 2013: 31; Schmalz and Dörre, 2016: 227-30). Societal power indicates the support of different social groups secured by unions due to the prestige they have and/or the popular demand of justice with which they can resonate (Frege and Kelly, 2004; Hyman and Gumbrell-McCormick, 2013: 31; Schmalz and Dörre, 2016: 230-33).

The power resources approach offers a way to explain the agency of workers and unions. It elaborates the objectivities of this agency, while subjectivities are given much less attention. More recently, some scholars have added the concept of capabilities to the model in order to scrutinise the actors' subjectivities more closely. For instance, Lévesque and Murray (2010) identify four capabilities - intermediating, framing, articulating and learning. They argue that how far unions can access power resources and how efficiently they can employ these resources depends on union leaders' capabilities. But what about the question of will and intention?

This question merits attention. Burawoy (2010: 303) identifies the power resources approach with "unstated optimism", because it "assumes that labor is always interested in resisting exploitation and its success depends on its capacity, that is the mobilization of two types of resources - structural and associational power". Burawoy (2011: 73) also points at the impact of the hegemony and ideology, which set limits on the agency. Moreover, as Thompson (1991: 266) shows, for the workers there are always many other and quite rational alternatives of "individualistic and familial strategies of survival". In my field research, I observed such strategies of survival and enrichment as the alternatives of acting collectively and organising against exploitation (Birelma, 2016: 208-10). Similarly, just like workers, which they were once a part of, union leaders can also have a wide range of different intentions and motivations other than merely organising and class struggle (Erem, 2001; Hyman, 2001; Jacobs, 2006; Dinler, 2014).

The power resources approach assumes a more or less particular subjectivity, although subjectivity is not less complicated than the objectivity (Bourdieu, 2000: 164-205; Ortner, 2006: 10755). I contend that the power resources approach alone cannot understand labour's agency. In order to balance the attention given to objectivities, it should be complemented with an analysis of subjectivities. While power resources offer an elaborate model of the labour movement's objectivities, we do not yet have a model of its subjectivities as elaborate and recognised. To analyse 
the impact of union leaders' subjectivities on the revitalisation, I build on Hyman's (2001) ideal types of unionism, the importance Ganz (2000) attributed to the leaders' motivations, the research on the importance of union ideology (Darlington, 2009; Benassi and Vlandas, 2016), and Lévesque and Murray's (2010) work on capabilities.

More concretely, I argue that TÜMTIS's revitalisation cannot be explained without taking both its objectivities and subjectivities into account. Without recognising TÜMTİS's leaders' class unionism (Hyman, 2001: 36), socialist ideology (Darlington, 2009: 8) and ensuing intrinsic motivations (Ganz, 2000: 1014), it is impossible to understand their success. Similarly, these by themselves cannot explain the success either, because some specific structural and associational power resources served as opportunities paving the way for the victories. More specifically, on the question of which power resource has been more prominent for the revitalisation, I will contend that associational power from below at the workplace level has been key throughout for TÜMTIS's revitalisation, on which everything else was built.

\section{A Short History of TÜMTiS's Revitalisation}

The Turkish labour movement has been one of those hit hardest by neo-liberal restructuring. The credible data on collective bargaining agreements is a viable measure to assess union power. ${ }^{2} \mathrm{I}$ calculate collective bargaining coverage in terms of the proportion of the total number of employees, including civil servants and informal workers, covered by a collective bargaining agreement. While nearly one in four employees was covered by a collective bargaining agreement in the mid-1980s, the continuous fall led to a rate of 5 per cent in 2013. Accordingly, wage shares have followed the plummeting strike rates, reaching new lows since the mid-1990s (Birelma, 2017).

After the 2001 economic crisis the unemployment rate was never lower than 9 per cent, while it rose above 10 per cent after the 2008 crisis. Subcontracted employment is the most common version of flexible employment, and the ratio of subcontract workers to the total number of employees grew from 4 to 11 per cent between 2002 and 2011 (Birelma, 2017).

One party governments of the pro-Islamic Justice and Development Party (AKP) since 2002 followed a two-fold strategy about unions. On the one hand, the AKP has limited the activities of left-wing, militant unions, including by prohibiting strikes. On the other, it colonises trade unions by embracing "symbiotic syndicalism" (Çelik, 2015) and fully supporting pro-Islamic and pro-AKP unions to the detriment of others (Doğan, 2013; Gürcan and Mete, 2017: 111). This formidable context, where all power resources of trade unions not aligned with the AKP have been dwindling, makes TÜMTIS's revitalisation even more fascinating.

\section{TÜMTIS before revitalisation}

Drivers of municipal buses and trams in Istanbul established TÜMTIS in 1949. It was among the

\footnotetext{
${ }^{2}$ The Turkish industrial relations regulatory regime does not provide any supportive mechanism for collective bargaining. Turkish unions must organise workplace by workplace to extend collective bargaining coverage. To be covered by a collective contract, a worker must be a union member, and the union has to be officially recognised in the workplace by organising more than half of the workers. Since 2012, the threshold for companies having more than one workplace is 40 per cent of total workers of the company.
} 
founding unions of the oldest and largest trade union confederation of Turkey, Türk-Iss, founded in 1952. TÜMTİS was led by a politically right-wing leadership and Istanbul remained its stronghold. Reporting its largest number of members in 1970 as 21 000, the union has never been a large one. ${ }^{3}$ It suffered two setbacks in its history. The first, in 1974, occurred when the government enacted a new regulation which redefined industries and excluded municipal bus services from the land transport sector. $^{4}$ This caused TÜMTIS to lose almost half of its membership. The second setback, the antilabour coup of 1980, resulted in a further decrease of the membership. Nevertheless, the union leadership praised the coup due to its right-wing stance (Pala, 1969; Baydar, 1998; T.S.A., 1998).

To survive, in the mid-1980s TÜMTIS engaged in organising the workers of the traditional, small-scale freight companies in Istanbul. These companies usually employed fewer than fifty workers, a considerable proportion of which were employed in an unregistered way. Thanks to this drive, the union grew but at a slow pace. Because the union's financial resources were extremely depleted, the professional leaders were paid no more than its members, which became a custom of the union.

At the end of the 1980s, Turkish labour made a comeback for a limited period, especially in terms of strikes. TÜMTİS participated in this wave by organising a series of strikes (Doğan, 2015: 396) and this activism led to a significant change in the leadership. A group of left-leaning workers won the executive election in 1989. With their energy and militancy, TÜMTIS revived itself as a small but solid union of small-sized freight company workers, who are almost exclusively men (Selçuk, 2002: 229). In the following years, the new leadership built close ties with a small socialist party.

In the first few years of the 2000s the union experienced a period of lethargy, internal debate and ensuing regression. Nearly a thousand union members working in the small-scale delivery companies in Istanbul left TÜMTİS and joined another union. Moreover, the small freight companies were losing their share of the market to the growing large-scale companies. The most significant success in this period was the organising of 200 bus drivers working in a subcontracted company serving a municipality in southeast Turkey. Due to various deadlocks and disagreements, in 2004 a group of leaders and members began to oppose the union leadership. After a period of harsh internal debate, the opposing group, led by the local leader of the successful campaign in the municipality subcontractor, won the executive election in 2007. The new leadership broke from the socialist party, which they blamed for backing the ex-leadership. This change of leadership marked a milestone in the union's history.

\section{First step: the search for revitalisation (2007-2009)}

In 2008, the union began to organise in two subcontractor companies working for Unilever, which triggered the firms to dismiss eighty-seven union members. This was the first time that the union had tried to organise an international firm and that it had got closer support from the International

\footnotetext{
3 Turkish unions' declarations about the numbers of their members have been greatly exaggerated. The Ministry of Labour put a digital system into force and began to declare the number of members in a relatively reliable way only as late as 2013 .

${ }^{4}$ Turkish labour law allows a union to organise only the workers of a specific industry, and industries are defined by the Ministry of Labour in an arbitrary way.
} 
Transport Workers' Federation (ITF). After a seven-month struggle, the union achieved the return of most of the workers. Nevertheless, it could not sign a collective agreement in the following months because of a court decision which determined that the firm was not a road transportation firm.

In the summer of 2008 the union successfully organised nearly 300 workers of a subcontracted firm at a dock in southern Turkey owned by an international firm. The employer gradually dismissed 197 members, who sustained a picket line for six months. The ITF supported the case by visiting the picket line and pressuring the parent company in Singapore via its member Singapore dockers' union (Anderson, 2015: 54). TÜMTIS achieved the reinstatement of all dismissed workers and it signed a collective bargaining agreement at the beginning of 2010. However, because the managers of the dock were anxious about the mobilising stance of TÜMTIS, they transferred all the union member subcontracted workers to its own firm in 2012. After this transfer, workers could not hold membership of the union, because the Ministry of Labour counts dockworkers as workers of a different industry from the road transport industry.

\section{Second step: a strategic choice to organise a big player (2009-2011)}

The real breakthrough was the United Parcel Service campaign that began at the end of 2009. TÜMTIS and other unions had tried to organise large-scale freight transport companies in the past, but these attempts had failed (T.S.A., 1998: 311). TÜMTIS targeted UPS because it was an international company with no history of failed organising drives. The new leadership saw an opportunity to build a campaign with support from the ITF. UPS Turkey had nearly 2500 directly employed workers and an estimated 2000 subcontracted and franchise workers at that time.

The union reached out to UPS workers in Istanbul and Izmir, and the UPS management began firing union members in April 2010. TÜMTISS responded by establishing picket lines of sacked workers in front of three UPS transfer centres in Istanbul and Izmir. At that time, the union had less than 400 members among direct and subcontracted workers. In the company's union-busting process, 162 TÜMTIS members were fired and most of them joined the picket line.

The picket lines and ITF-led international campaign lasted for nine months. Thanks to their combined pressure, UPS and TÜMTİS came to an agreement in February 2011. All but twelve of the sacked workers were reinstated and UPS management declared that it would respect the unionisation. ${ }^{5}$ In July, the number of union members exceeded the company threshold of 40 per cent and TÜMTIS got the recognition from the Ministry. The ensuing collective bargaining led to the agreement signed in December 2011. During the negotiations, many non-member workers became union members, and a number of subcontracted workers became directly employed. When the agreement was signed, TÜMTİS had nearly 2700 members among UPS workers.

\section{Third step: letting success breed success (2012-2014)}

In close coordination with the ITF, TÜMTIS leaders chose the German Deutsche Post's DHL as the second target. This time UNI Global Union (UNI) was a more integral part of the process, because ver.di, the union organising in DHL's home country, is a UNI affiliate. In spring 2012 TÜMTIS began to get in touch with DHL workers. In June DHL found out about the drive and fired thirty-

${ }^{5}$ For the details of the campaign see Dinler and McGrath (2011). 
seven union members; TÜMTIS responded with two picket lines in Istanbul and Kocaeli. DHL was even more obstinate than UPS about opposing unionisation, which led to a fifteen-month-long picket-line campaign. UNI and ITF targeted shareholders and customers of DHL. Among other things, they filed a complaint against DHL with the German Government, alleging a breach of the OECD Guidelines for Multinational Enterprises in Turkey and other countries. ${ }^{6}$

Thanks to this multi-dimensional pressure, DHL gave up its hostility in autumn 2013. After the recognition and collective bargaining processes, TÜMTİS finally signed a collective contract in April 2014 with DHL for its 2260 members. All but seven of the sacked workers were reinstated, wages were increased by around 40 per cent, and 730 subcontracted workers were transferred to permanent positions. DHL's union-busting campaign was so uncompromising that it provoked both leaders and members of TÜMTIS to be as stubborn as possible during collective bargaining, which resulted in a stronger first agreement compared to UPS.

\section{Fourth step: expanding the campaign to sustain success (post-2014)}

TÜMTİS's third target was the second-largest firm in the Turkish freight transport industry, Aras Delivery. Employing nearly five thousand workers, Aras is owned by a Turkish family, with Austrian Post having a 25 per cent share. In nearly a year and a half, by the end of 2015, TÜMTİS had recruited nearly 2000 members among Aras workers, which was enough for recognition, and it applied to the Ministry to obtain it. This time TÜMTIS had followed a less contentious strategy, because the management of Aras had been less aggressive compared to earlier cases. Nevertheless, the management refused to respect TÜMTIS's declaration of having enough members for recognition and brought the case to court. ${ }^{7}$ In September 2017, the local court recognised TÜMTİS, but Aras's management brought the case to the court of appeal. The appeal process had not been concluded at the time of writing. TÜMTIS leaders expect to win the case and to sit at the bargaining table with Aras by summer 2018. ${ }^{8}$

In ten years, TÜMTIS increased the number of its due-paying members working under collective contracts from around 1500 in 2007 to nearly 6500 in 2017 . While the number of workers under collective contracts in Turkey increased by 22 per cent in the same period, the rate for TÜMTIS is more than 300 per cent. ${ }^{9}$ Since January 2013, the Ministry of Labour has begun to publish reliable statistics on union membership in Turkey. Between January 2013, when the DHL picket line was going on, and January 2018, TÜMTIS increased its total membership (which includes members with no collective contract yet) from 6775 to 8873 .

TÜMTIS had to deal with a court decision which reveals the extreme difficulties of class

${ }^{6}$ For the details of this campaign see Conrow (2015: 109-16).

7 The union law grants this right to employers, and they mostly use it to prolong the process of recognition. Including the process of appeal, these cases last usually around one and a half years, and sometimes even longer.

8 The union also applied for recognition at DHL Express, a DHL group company specialising in international delivery, but once again DHL management fired union members. In response, TÜMTIS picketed the company's headquarters in July 2017 and started an international campaign with the ITF.

9 The 22 per cent increase in the general rate is mostly due to unionisation in the public subcontractor companies, mainly by AKP unions. To understand this process, see Birelma (2017). 
unionism in the Turkish context. In March 2017, the Turkish Court of Appeal made a decision involving fourteen TÜMTIS leaders and members of the Ankara local. In 2012, the local court had sentenced them to prison terms ranging from one and a half to six years due to a complaint by a freight company where TÜMTIS had tried to organise in 2007. The sentence was for the "crimes" of "increasing the number of members and thus obtaining more dues" and "obstructing the freedom of work" (Çelik, 2017). After the Court of Appeal upheld the lower court's finding, which was shocking even in terms of the declining Turkish legal standards, the fourteen unionists were imprisoned.

\section{Analysis of TÜMTiS's Evolution and Success}

\section{Subjectivities: ideology and motivations}

TÜMTİS had a socialist leadership affiliated with a political party since 1989, which gave the union a militant, activist and mobilising stance and external allies. However, such a leadership might also cause serious problems if partisan politics take precedence over unionism. This seems to be what the union experienced in the early 2000s, at a time when socialist parties and factions in Turkey experienced marginalisation without exception. Another factor seems to be the loss of enthusiasm and dynamism on the part of the union leader, who had held the position for eighteen years. The new leadership, which took over in 2007, put an end to their allegiance to the party while maintaining their socialist ideology. ${ }^{10}$

As Darlington (2009: 5) notes, "the relative neglect of the whole topic of left-wing union leadership and its significance for collective mobilization" is "a common feature of much industrial relations literature generally". Similarly, Benassi and Vlandas (2016: 19) argue that ideological factors are as important as institutional ones to explain unions' bargaining strategies. The two-centuries-long history of European labour movements reveals that for unions in general, socialism tends to become elusive, becoming at best a form of rhetoric in the long run (Hyman 2001: 17-37). Nevertheless, as Darlington (2009: 27) reminds us, there are exceptions, and a left-wing union leadership has an advantage to demonstrate a relatively better "ability to deliver in terms of obtaining real and demonstrable material improvements in pay and conditions", because of its "combative stance, often involving the collective mobilization of members and the threat and use of strike action". In the end, as Hyman (2001: 36) puts it, class unionism is a "necessity" as much as an "impossibility".

"Class unionism" is the last one of Hyman's (2001: 1-65) three ideal types of unionism. In the first, unions are interest organisations with mainly labour market functions. In the second, they are members of civil society and vehicles for raising workers' status in society. In the third, unions are class actors and "schools of war" in a struggle between labour and capital. Obviously, the real unions "have tended to incline towards an often contradictory admixture of two of the three ideal types" (Hyman, 2001: 4). Related to their socialist orientations, TÜMTIS's leadership embraces a comparatively higher level of class unionism.

Socialist orientation here means a set of values quite like Darlington's (2009: 8) description of the left-wing politics of another transportation workers' union, the National Union of Rail, Maritime

${ }^{10}$ For IG Metall in Germany, Schmalz and Thiel (2017) emphasise the importance of the election of a new national leadership for the ensuing revitalisation of the union.

Global Labour Journal, 2018, 9(2), Page 222 
and Transport Workers (RMT) in Britain: "the syndicalist-type sense of a consistently adversarial attitude towards management and a commitment to the wholesale redistribution of wealth and power in society". Indeed, TÜMTİS leadership defines and imagines itself as part of a collective agency, which has the potential to change not only working conditions but also the entire political and economic system. It embraces a greater goal than bread-and-butter issues and aims for the empowerment of the working class against capital. The leaders declare this goal through a rather subpolitical discourse that does not alienate workers but that resonates with their daily lives and problems. What motivates the average worker to join TÜMTİS is not its left-wing stance per se. Thanks to their politics, TÜMTÍS leaders adopt a combative and mobilising stance which leads to greater success in terms of gaining improvements. The mobilising way of unionism "boosts members' self-confidence and their sense of collective power, and in turn encouraged union activism and recruitment" as Darlington (2009: 20) also observes.

Another subjective factor which contributes to success is the greater motivation and commitment of 'TÜMTİS's leadership than the average Turkish unionist. In his brilliant account of the impact of motivation, Ganz (2000: 1014) underlines that union leaders who are committed to their job personally and/or vocationally instead of professionally enjoy more intrinsic rewards, which brings greater motivation and creativity.

The fact that union leaders earn no more than the maximum wage earned by union member workers is very coherent and impressive in this sense. The modesty of the leaders and, for example, of their rooms in the union headquarters is striking. The relationship and interaction between leaders and members are not limited to collective bargaining agreements every two years, which is different from most of the Turkish unions. The union leaders and professionals are quite accessible to grassroots members, so that the leaders and professionals visit and interact with members on a daily basis. Leaders believe that they "share a common fate" with their members and they work hard to act accordingly. ${ }^{11}$

\section{Objectivities: power resources that TÜMTIS has tapped into}

Institutional power has not been great for Turkish unions since the anti-union coup of 1980. However, this statement is no longer generalisable for all unions, because those that have a leadership close to the AKP have been enjoying a great level of institutional power since the mid2000s. TÜMTIS is not one of them. Societal power of Turkish unions in general is not considerable either. Because most of the Turkish unions have become interest organisations caring only about their shrinking number of members and the AKP's skill to exploit this tendency (Buğra, Adanır and Insel, 2009; Doğan, 2013: 191), the prestige of unions has eroded progressively. Therefore, TÜMTİS has access mainly to two power resources, structural and associational, and the most crucial one for its revitalisation has been the latter. Below I examine structural power, which TÜMTIS employed secondarily, and then I discuss its associational power.

${ }^{11}$ I do not claim that all the professional leadership of TÜMTIS share this rather high level of political motivation, enthusiasm and tenacity. However, I observed that this relatively high level of commitment is the main tendency in the head office of the union.

Global Labour Journal, 2018, 9(2), Page 223 
The high structural power of transportation workers

Wright (2000: 962) and Silver (2003: 13) identify two types of structural power. "Marketplace bargaining power" derives from having scarce and demanded skills within the labour market. "Workplace bargaining power", on the other hand, derives from the strategic position of a group of workers within the capitalist economy or within a particular workplace. As Silver (2003: 98-100) notes, transportation workers "have possessed and continue to possess relatively strong workplace bargaining power" and therefore their unions tend to be stronger and more militant. For the specific industry where TÜMTIS has mostly organised, namely freight logistics, Anderson (2015: 55) underlines the "time-sensitive" nature of the industry and points at the same power resource by stating that "even minor delays can impact on revenue streams". In her research on workers' protests between 1870 and 1996, Silver (2003: 98) finds that transportation ranks on top among other industries. It is safe to argue that this higher tendency to protest is reinforced by relatively strong workplace bargaining power enjoyed by this industry's workers. As Wright (2000: 962) notes, "structural power may itself influence associational power".

Indeed, during the extension of the membership base in small-sized delivery firms between the mid-1980s and the early 2000s, TÜMTİS organised many formal or informal strikes and they seemed to be quite effective, as reinforced by the structural advantage of transportation workers (T.S.A., 1998: 311; Selçuk, 2002: 230, 232; Doğan, 2015: 396). The union's efficacy in satisfying its members' demands in its stronghold of small freight companies leads to a greater identification among these members with the union. This membership base of workers identifying with the union, its goals, and activism - in a relatively greater sense - gave TÜMTIS its core associational power on which it could build everything else.

On the other hand, this workplace bargaining power based on the possibility of strike action is not automatic or generalisable in the industry. To be utilised, it seems to require the union to be organised in a significant number of firms of similar kind and size. During its organising campaigns in large companies such as UPS, DHL and Aras, and after it got recognition in the first two, TÜMTIS did not ever strike in these firms formally or informally. This is not only because a strike requires much larger strike funds. The real problem is the nearly two dozen unorganised large-sized freight companies, which would immediately take the orders of the affected firm due to the nature of the sector. "In case of a strike no company which has a contract with UPS for delivery would say let's wait for the strike to be resolved", as a union leader puts it. This would be devastating for the struck firm, leading to serious downsizing or even bankruptcy. Therefore, in its revitalisation process since the end of the 2000s, TÜMTİS seems to exploit this power resource in a quite limited way, probably only as a threat.

\section{Associational power}

In a context where all power resources have been almost depleted, TÜMTIS had nothing but its associational power to rely on and amplify. Schmalz and Dörre's (2016: 224-26) identification of different bases and levels of associational power will be useful for a thorough analysis. They define five different bases of associational power: number of members, infrastructural resources, organisational efficiency, member participation and internal cohesion. Furthermore, by building on Wright, they differentiate four levels at which associational power can be exercised: the workplace, the marketplace, the political system and the supranational level (Schmalz and Dörre, 2016; see also 
Schmalz, Ludwig and Webster, this issue).

As a small but socialist and mobilising union since the end of 1980s, TÜMTİS seems to have considerable associational power at the workplace level and at the marketplace level of the specific labour market of small-sized freight company workers. The bases of this associational power have been member participation and internal cohesion, which compensate for the limited number of members and infrastructural resources.

Due to very limited financial resources, the union never had a professional staff for organising until the ITF provided funding for the UPS campaign. Elected leaders do the job of organising themselves, with support from grassroots members. A number of lay members tend to support the organising drives in their area by contacting potential members. Moreover, many members working in small-sized freight companies make additional contributions, besides normal fees, when the union asks members to support it financially during an organising campaign.

Why does TÜMTIS have relatively high levels of member participation and internal cohesion? One factor is the special structural power the union has and its mastery to exploit this resource in its stronghold of small-sized freight companies. Because of their scrutinised subjectivities, the TÜMTIS leadership has also mastered framing and intermediation, two capabilities that further boost member participation and internal cohesion. As defined by Lévesque and Murray (2010: 343), "framing capabilities characterize a union's ability to define a proactive and autonomous agenda". Class unionism serves as a strong frame and advances TÜMTIS's framing capability, which gives the leadership a greater mobilising and liberating cause.

Intermediation, on the other hand, is the ability to "arbitrate between conflicting demands and to favour the emergence of collective interest" and "collaborative action" (Lévesque and Murray 2010: 341). Neither in an industry nor in a workplace are workers' interests naturally common. A group of leaders should create and maintain the perception that there are common interests (Hodson, 2001: 204-9; Kelly, 2002: 30-6). Intermediation comes into play at this point. The relatively high level of interaction between leadership and lay members functions as a form of intermediation that builds collective interests and identities. The TÜMTIS leadership works to deal with the problems of even individual workers through regular visits to workplaces. These visits also serve to transmit the messages of the union and to demand and mobilise members' support for the new organising drives. These interactions serve to raise awareness about the fact that the maintenance of their better working conditions rests on the organising of new workplaces. Furthermore, the union tries harder to operate internal democracy, especially during collective bargaining and organising campaigns.

The rise of the new leadership in 2007 intensified the associational power of the union thanks to the higher level of dynamism of the new leaders. More importantly, due to their capability of learning, new leaders discover and utilised a power resource which was untapped before the end of the 2000s, namely associational power at the supranational level.

\section{Tapping into associational power at the supranational level}

Despite its distinct framing and intermediation capabilities, strong membership participation, greater internal cohesion and dynamism of the new leadership, by the end of the 2000s TÜMTIS could not organise in a large workplace. The Unilever and dockworker cases were TÜMTİS's first attempts to organise at international firms. The ITF provided support to the union in both cases in more 
concrete ways than ever before. In accordance with the significance of this closer collaboration between TÜMTIS and the ITF, a special meeting was held at TÜMTİS headquarters in Istanbul in the summer of 2009. TÜMTİS leaders came together with five key ITF officials. The subject of the meeting was how to organise at large-scale international firms, and this meeting laid the foundation of the UPS campaign (TÜMTIS, 2011: 85). Since its 2006 Congress, the ITF has embraced an "Organizing Globally" strategy and developed union networks in "big four" transnational logistics companies, including UPS, to support further organising (Anderson, 2015: 50).

The global union federations are major players at the supranational level (Croucher and Cotton, 2009). Parallel with the global trend, Turkey witnessed an increasing involvement of GUFs in local campaigns in the 2000s. ${ }^{12}$ In countries where domestic power resources are in decline, labour movements tend to apply transnational strategies more often (Anner, 2011: 176). Moreover, as Silver (2003: 101) notes, "the material basis of labour internationalism is stronger among transport workers than among workers in manufacturing industries".

The ITF gave significant financial support to TÜMTIS to develop its infrastructural power resources. With its approach of strategic organising, the ITF also transferred specific organising know-how required by the task of unionising in a giant corporation and running an international campaign. Although TÜMTIS is quite experienced in organising small workplaces using loose and informal tactics, a giant corporation like UPS required a more sophisticated and longer-term strategy. TÜMTIS's relatively quick transformation from a local union organised in small workplaces into a respected, inspirational and integral member of the international labour movement organised in global corporations reveals that the union leadership showed significant learning capability.

During the campaigns, ITF and UNI unions, especially in Western countries, mobilised their associational power (by making the TÜMTIS case a bargaining issue in the firm's original country), its institutional power (through the OECD complaint in the DHL case ${ }^{13}$ ), and its societal power (by holding public protests to shame the firm and alienate customers). However, one should emphasise that this international support would have been in vain if TÜMTIS did not have crucial and quite rare subjectivity and capabilities as explained above. In fact, in terms of total membership, TÜMTIS's UPS victory was "the largest organizing victory in the logistics sector in the history of ITF’s Organizing Globally strategy” adopted in 2006 (Anderson, 2015: 56).

As Seidman (2008) and Anner (2011: 71) argue, transnational labour activism is not a panacea, and it can only succeed if it rests on the strong local activism of the local union. Indeed, as I confirmed from an ITF officer, the ITF's support for TÜMTIS rested on the latter's potential which ITF officers witnessed during the campaigns in 2008 and 2009. TÜMTİS did not disappoint them.

\section{Conclusion}

In this article, I have examined the quite extraordinary revitalisation case of a Turkish union, TÜMTIS. A small and local union having nearly 1500 members under collective contract won a unionisation campaign against a global giant, UPS, which led to nearly 2700 new members with a

12 Dinler and McGrath (2011), Dinler (2012), Korkmaz (2013) and Fichter, Sayım and Berber-Agtas, (2013) explore nearly ten different cases of international organising campaigns in Turkey.

${ }^{13}$ The complaint led to a joint statement by the German National Contact Point for the OECD guidelines for multinational enterprises, UNI, ITF and DHL at the beginning of 2014. See OECD (2014). 
collective contract. Subsequent organising victories at two other large-scale corporations, DHL and Aras, proved that the UPS victory was not an accident. The fact that the context of this revitalisation is Turkey, where all power resources of unions not aligned with the governing party have been dwindling, makes this success even more significant.

To analyse the case, I employ the power resources approach in a critical way. I contend that the approach enables the researcher to investigate in detail the objectivities of union agency. However, the power resources approach passes over the issue of subjectivity by assuming the prevalence of a particular subjectivity. Therefore, to the power resources analysis, I added an examination of the subjectivities of union leaders by drawing on debates about the importance of the ideology and motivations for the unions. I claim that TÜMTIS's revitalisation can be only explained by taking both the union objectivities and subjectivities into account. While class unionism embraced by its leaders explains the subjective side of the process, associational power from below at the workplace level plays a key role on the objective side. In the process, this associational power from below converged with with the associational power at the international level, both of which are influenced by the relatively greater structural power of transportation workers. This conjunction has brought the victories.

Beyond its recent successes, another factor which distinguishes TÜMTIS is its serious potential for growth. Nearly two dozen large-scale freight transport companies mark TÜMTIS's potential territory of growth. Being the second-largest firm of the delivery and freight transport industry in Turkey, the Aras campaign will be decisive in this sense. In the normal course of events it is more than likely that TÜMTIS will obtain recognition in Aras and DHL Express in 2018, which will turn it into a larger-scale trade union commanding much larger resources. This will open the way for the organisation of all major firms in the industry.

TÜMTİS's revitalisation and successes are still fragile and reversible, though. There are two risks, one external, the other internal, which might hinder the realisation of its potential. The external risk is the rise of right-wing authoritarianism and arbitrary rule in Turkey. This renders not only TÜMTIS but all egalitarian and democratic forces of the country increasingly vulnerable. The internal one is the risk of experiencing the fate of the ex-leadership. To resist the iron law of oligarchy, and at the same time to sustain the idealism and dynamism, as required by class unionism, under such formidable circumstances for many years is not an easy task. Even though I witnessed that there are people among the union's leadership who might not give up this mission impossible, there are limits of the individual agency against the institutions and structures.

TÜMTIS's fate will be dependent on how it manages these two risks. However, no one could ever deny or erase their inspiring struggles and victories in the last decade. The case of TÜMTIS's revitalisation reveals that a version of class unionism, which brings success, is not only a nostalgia of the past or a possibility in the distant future, but it exists here and now. It shows that hope and the struggle for it are still alive. That is "the most beautiful hope of the modern age: the hope that we can make the ideals of equality, freedom, and solidarity real simultaneously" (Buğra, 2010: 210).

\section{REFERENCES}

Anderson, J. (2015) Towards Resonant Places: Reflections on the Organizing Strategy of the International Transport Workers' Federation. Space and Polity, 19(1): 47-61. 
Anner, M. (2011) Solidarity Transformed: Labor Responses to Globalization and Crisis in Latin America. New York: Cornell University Press.

Baydar, O. (1998) Trade Unions in Turkey. İstanbul: Friedrich Ebert Stiftung.

Benassi, C. and T. Vlandas (2016) Union Inclusiveness and Temporary Agency Workers: The Role of Power Resources and Union Ideology. European Journal of Industrial Relations, 22(1): 5-22.

Birelma, A. (2016) In Search of the Working Class: Workers' Subjectivities and Resistance in an Istanbul Neighborhood. Unpublished PhD dissertation, Bogazici University, Istanbul.

Birelma, A. (2017) Subcontracted Employment and the Labor Movement's Response in Turkey. In Uncertain Times: Anthropological Approaches to Labor in a Neoliberal World, edited by P. Durrenberger. Boulder, CO: University of Colorado Press.

Bourdieu, P. (2000) Pascalian Meditations. Stanford, CA: Stanford University Press.

Buğra, A., F. Adanir and A. İnsel (2009) Societal Context of Labor Union Strategy: The Case of Turkey. Labor Studies Journal, 34(2): 168-88.

Buğra, A. (ed.) (2010) Simftan Simifa. İstanbul: İletişim.

Burawoy, M. (2010) From Polanyi to Pollyanna: The False Optimism of Global Labour Studies. Global Labour Journal, 1(2): 301-13.

Burawoy, M. (2011) On Uncompromising Pessimism: Response to my Critics. Global Labour Journal, 2(1): 7377.

Çelik, A. (2015) Turkey's New Labour Regime under the Justice and Development Party in the First Decade of the Twenty-first Century: Authoritarian Flexibilization. Middle Eastern Studies, 51(4): 618-35.

Çelik, A. (2017) Sendikacıllğa yarg1 darbesi. Birgün Gazetesi, Istanbul. https://www.birgun.net/haberdetay/sendikaciliga-yargi-darbesi-151671.html (accessed 16 May 2017).

Conrow, T. (2015) Developing Strategic Campaigns. London: International Transport Workers' Federation.

Croucher, R. and E. Cotton (2009) Global Unions, Global Business. London: Middlesex University Press.

Darlington, R. (2009) Leadership and Union Militancy: The Case of the RMT. Capital \& Class, 99: 3-32.

Dinler, D. (2012) Country Trade Union Report: Turkey. İstanbul: Friedrich Ebert Stiftung.

Dinler, D. (2014) Isşsinin Varlk Problemi. İstanbul: Metis.

Dinler, D. and M. McGrath (2011) Strategic Campaigning in Multinational Companies: The Case of United Parcel Service (UPS) in Turkey. Juridikum, 3: 373-84.

Doğan, G. (2013) 1980 Sonrası Sendikal Hareket: Türkiye'de Sendikacıllı̆ın Kuğu Şarkısı. In Tan₹̧imattan Günümüze Türkiye İşi Sımfi Taribi 1839-2014, edited by D. Çetinkaya and M. Alkan. İstanbul: Tarih Vakf1 Yurt Yayınları.

Doğan, G. (2015) The Deradicalisation of Organised Labour. In Turkey Reframed: Constituting Neoliberal Hegemony, edited by İ. Akça, A. Bekmen and B. Özden. London: Pluto.

Erem, S. (2001) Labor Pains: Inside America's New Union Movement. New York: Monthly Review Press.

Fichter, M., Z. Sayım and Ö. Berber-Agtas (2013) Organization and Regulation of Employment Relations in Transnational Production and Supply Networks. Ensuring Core Labor Standards through International Framework Agreements? Report Turkey. Berlin: Friedrich Ebert Stiftung.

Frege, C. and J. Kelly (2004) Union Strategies in Comparative Context. In Varieties of Unionism, edited by C. Frege and J. Kelly. New York: Oxford University Press. 
Ganz, M. (2000) Resources and Resourcefulness: Strategic Capacity in the Unionization of California Agriculture, 1959-1966. American Journal of Sociology, 105(4): 1003-62.

Gürcan, E. and B. Mete (2017) Neoliberalism and the Changing Face of Unionism. Cham, Switzerland: Palgrave Macmillan.

Hodson, R. (2001) Dignity at Work. Cambridge: Cambridge University Press.

Hyman, R. (2001) Understanding European Trade Unionism: Between Market, Class and Society. London: Sage.

Hyman, R. and R. Gumbrell-McCormick (2013) Trade Unions in Europe: Hard Times, Hard Choices. Oxford: Oxford University Press.

Jacobs, J. (2006) Mobsters, Unions, and Feds: The Mafia and the American Labor Movement. New York: New York University Press.

Kelly, J. (2002) Rethinking Industrial Relations: Mobilization, Collectivism and Long Waves. London: Routledge.

Korkmaz, E. (2013) Globalisation, the Global Labour Movement and Transnational Solidarity Campaigns: Three Case Studies from Turkey. SEER Journal for Labour and Social Affairs in Eastern Europe, 1: 97-112.

Lévesque, C. and G. Murray (2010) Understanding Union Power: Resources and Capabilities for Renewing Union Capacity. Transfer, 16(3): 333-50.

Organisation for Economic Cooperation and Development (OECD) (2014) Joint Final Statement by the German National Contact Point for the OECD Guidelines for Multinational Enterprises (NCP), UNI Global Union (UNI) and International Transport Workers' Federation (ITF) and Deutsche Post DHL (DP-DHL) on the Complaint by UNI/ITF against DP-DHL/Bonn. Berlin. http://www.bmwi.de/Redaktion/DE/Downloads/G/gemeinsame-abschlusserklaerung-deutschenationale-kontaktstelle-englisch-itf-dhl.html (accessed 5 January 2017).

Ortner, S. (2006) Anthropology and Social Theory. Durham, NC: Duke University Press.

Pala, H. (1969) Türk Sendikacllk. Hareketi İçinde TÜMTIS' in 20 Yll. İstanbul: TÜMTIS.

Schmalz, S. and K. Dörre (2016) The Power Resources Approach. Paper presented at the Trade Unions in Transformation Authors' Workshop, Berlin.

Schmalz, S. and M. Thiel (2017) IG Metall's Comeback: Trade Union Renewal in Times of Crisis. Journal of Industrial Relations, 59(4): 465-86.

Seidman, G. (2008) Transnational Labour Campaigns: Can the Logic of the Market Be Turned against Itself? Development and Change, 39(6): 991-1003.

Selçuk, F.Ü. (2002) Örgütsüəlerin Örgütlenmesi. Ankara: Atölye.

Silver, B. (2003) Forces of Labor: Workers' Movements and Globalization Since 1870. Cambridge: Cambridge University Press.

Thompson, E.P. (1991) Customs in Common. London: Penguin.

Tilly, C. (1995) To Explain Political Processes. American Journal of Sociology, 100: 1594-1610.

Türkiye Sendikacılık Ansiklopedisi (T.S.A.) (1998) TÜMTİS. İstanbul: Tarih Vakfi.

Tüm Taşıma İşçileri Sendikası (TÜMTİS) (2011) Olağan Genel Kurulu Çalşsma Raporu 2008-2011. Istanbul: TÜMTİS.

Wright, E.O. (2000) Working-class Power, Capitalist-class Interests and Class Compromise. American Journal of Sociology, 105(4): 957-1002. 


\section{BIOGRAPHICAL NOTE}

ALPKAN BIRELMA is an assistant professor in the Department of Humanities and Social Sciences at Özyeğin University, Istanbul. A sociologist by training, Birelma works on labour movements, sociology of work and social classes. He has been volunteering in various labour organisations in Turkey since his undergraduate years. [Email: alpkan.birelma@,ozyegin.edu.tr] 